\title{
Analisis Faktor-Faktor Yang Mempengaruhi Service Excellence (Studi Kasus Pada PT. Bank X (Persero), Tbk. Pekanbaru)
}

\author{
Abdul Jalal \\ Universitas Riau, Pekanbaru, Riau 28293, Indonesia
}

\begin{abstract}
ABSTRAK : Service excellence menjadi hal yang penting bagi dunia perbankan di Indonesia.Penelitian ini menganalisis faktor-faktor yang mempengaruhi service excellence di PT. Bank X (persero), Tbk. Pekanbaru.Rumusan masalahnya adalah bagaimana mewujudkan service excellence.Penelitian ini mengembangkan model penelitian dan tiga hipotesis guna menjawab permasalahan yang ada.Responden dalam penelitian ini sebanyak 102 orang.Para responden tersebut merupakan para karyawan di PT. Bank X (persero), Tbk. Pekanbaru.Penelitian ini menggunakan Statistical Package for Social Science (SPSS) 17.0 sebagai alat analisisnya.Hasil analisis data menunjukkan bahwa model penelitian dan hasilnya dapat diterima.Hasil penelitian membuktikan bahwa interaksi antar departemen, sistem informasi pemasaran dan sistem kontrol mempunyai pengaruh positif dan signifikan terhadap service excellence. Semakin interaksi antar departemen, sistem informasi pemasaran dan sistem kontrol maka akan semakin tinggi pula service excellence yang diberikan kepada nasabah.

Berdasarkan hasil penelitian ini maka implikasi teoritis yang dapat memberikan justifikasi yang lebih kuat bagi variabel yang mempengaruhi service excellence, seperti interaksi antar departemen, sistem informasi pemasaran dan sistem kontrol.Implikasi manajerial dari penelitian ini adalah pihak manajemen Bank X perlu mempertahankan serta lebih meningkatkan terhadap upaya evaluasi aktivitas dan umpan balik yang sudah dilakukan, senantiasa meningkatkan hardware dan software sistem informasi pemasaran serta meningkatkan komunikasi antar departemen sehingga pencapaian service excellence yang diharapkan dapat senantiasa terwujud.

Berdasarkan atas keterbatasan yang ada, agenda untuk penelitian mendatang perlu menambahkan variabel-variabel yang mempengaruhi service excellence dan memperbaiki metode pengambilan sampelnya.
\end{abstract}

Kata kunci:interaksi antar departemen; sistem informasi pemasaran; sistem kontrol dan service excellence

\begin{abstract}
Service excellence is become an important thing for banking in Indonesia. This research analyzes factors influencing service excellence in PT. Bank X (persero), Tbk. Pekanbaru. The research problem is how to increase service excellence. This research builds a model and three hypotheses to answer the research problem. Respondents of this research are 102 persons. Respondents are staff of Bank X. This research uses Statistical Package for Social Science (SPSS) 17.0 program as analysis tools. The data analysis result of this research shows that research model and result can be accepted. The result of the research proves that interaction between departements, marketing information system and control system have positive and significant influence to service excellence. The higher interaction between departements, marketing information system and control system, the higher service excellence.

Based on the results of the research could be taken theoretical implications that this research gives more justification for antecedents positively influence service excellence, i.e.: interaction between departements, marketing information system and control system. Managerial implications of this research are Bank X management need to pay attention to activity evaluation and it feed back, Bank X management need to always upgrade hardware and software marketing information system, and bank $\mathrm{x}$ management need to increase communication between departments so that service excellence is always expected to realized.

Based on the limitation, agenda for future research are adding other variables influencing service excellence and repairing sampling method
\end{abstract}

Keywords:interaction between departments, marketing information system, control system and serviceexcellence

Email Addres : abduljalal@umrah.ac.id 


\section{Pendahuluan}

Kekuatan perubahan pada dunia perbankan telah bergerak menuju orientasi strategi pelanggan.Service excellence menjadi faktor utama yang membedakan bank dan sangat menentukan apakah mereka mampu bertahan hidup atau tidak (Seonmee Kim and Brian H. Kleiner .1996, Vol. 6)

Service excellence merupakan kepedulian kepada pelanggan dengan memberikan layanan terbaik untuk memfasilitasi kemudahan pemenuhan kebutuhan serta mewujudkan kepuasan agar selalu loyal kepada perusahaan. Efek dari service excellence adalah sangat menguntungkan bank. Ini dapat membantu pemotongan biaya dimana karyawan lebih memperhatikan secara detail dengan mengurangi kesalahan dan melakukan koreksi yang terkait serta dapat juga meningkatkan pendapatan dengan meningkatkan loyalitas pelanggan.

Menurut Parasuraman, et al. yang mengemukakan teori Servqual (service quality) menyatakan bahwa kualitas layanan merupakan perbandingan antara layanan yang dirasakan (perception) konsumen dengan kualitas layanan yang diharapkan konsumen. Jika kualitas layanan yang dirasakan melebihi kualitas layanan yang diharapkan, maka layanan itu dikatakan service excellence. Lima hal yang mencakup dalam service excellence menurut Parasuraman (1988), yaitu : keandalan (reliability) merupakan kemampuan bank untuk memberikan pelayanan yang tepat, dapat diandalkan dan dapat dipercaya, kepastian jaminan (assurance) merupakan kemampuan bank atau karyawan untuk memberikan pelayanan yang dapat menimbulkan kepercayaan nasabah kepada bank dan rasa aman nasabah dalam melakukan transaksi dengan bank, bukti layanan (tangibles) merupakan kemampuan bank dalam menyediakan fasilitas fisik, misalnya ruang tunggu yang bersih dan nyaman, ATM yang memiliki beragam fungsi, jaringan ATM yang luas dan berpenerangan cukup, serta penampilan personel, baik petugas satuan pengamanan (satpam) maupun karyawan kantor yang selalu rapi, empati (empathy) merupakan suatu bentuk perhatian yang umumnya disenangi setiap orang dimana bank mampu memahami apa yang dibutuhkan nasabahnya sehingga nasabah merasa kepentingannya lebih diutamakan dan ketanggapan (respons) merupakan kesediaan bank untuk membantu nasabah bila nasabah mengalami masalah dan tidak membiarkan nasabah menunggu atau mengantri terlalu lama untuk dilayani.

PT Bank X (Persero) Tbk. merupakan bank terbesar di Indonesia dalam hal aset, pinjaman, dan deposit. Pada Tahun 2010 Bank X memiliki asset sebesar Rp 371,67 Triliun menyusul Bank Rakyat Indonesia dengan asset Rp 306,76 Triliun. Bank X tidak hanya dikenal sebagai bank terbesar di Indonesia tetapi juga sebagai bank yang memiliki service excellence tertinggi diantara seluruh bank yang ada di Indonesia. Hal ini dibuktikan dengan diraihnya Best Service Excellence empat tahun berturutturut yaitu tahun 2008, 2009, 2010 dan 2011 menurut sebuah lembaga independen penilai pelayanan publik yaitu Marketing Research Indonesia (MRI) Infobank, 2011. Dengan hasil ini Bank $\mathrm{X}$ berhasil mematahkan persepsi masyarakat tentang pelayanan yang buruk terhadap sebagian besar instansi pemerintah yang tidak terkecuali bank pemerintah.

Untuk lebih jelasnya mengenai urutan 10 besar perbankan di Indonesia dari segi asset pada tahun 2010 dapat dilihat pada Tabel 1berikut ini. 
Tabel 1 : 10 Besar Pangsa Aset Perbankan IndonesiaPer Desember 2010

\begin{tabular}{|l|l|c|c|}
\hline $\mathbf{P}$ & \multicolumn{1}{|c|}{ Nama Bank } & $\begin{array}{c}\text { Total } \\
\text { Asset }(\mathbf{R p} \\
\text { Triliun) }\end{array}$ & $\begin{array}{c}\text { Pangsa } \\
\text { Pasar } \\
\mathbf{( \% )}\end{array}$ \\
\hline 1 & Bank X Rakyat & $\mathbf{3 7 1 , 6 7}$ & $\mathbf{1 3 , 7 6}$ \\
\hline 2 & $\begin{array}{l}\text { Bank } \\
\text { Indonesia }\end{array}$ & $\mathbf{1 1 , 3 6}$ \\
\hline 3 & $\begin{array}{l}\text { Bank Central } \\
\text { Asia }\end{array}$ & $\mathbf{3 0 5 , 1 5}$ & $\mathbf{1 1 , 3 0}$ \\
\hline 4 & $\begin{array}{l}\text { Bank Negara } \\
\text { Indonesia }\end{array}$ & $\mathbf{2 1 7 , 0 7}$ & $\mathbf{8 , 0 4}$ \\
\hline 5 & $\begin{array}{l}\text { Bank CIMB } \\
\text { Niaga }\end{array}$ & $\mathbf{1 2 6 , 9 6}$ & $\mathbf{4 , 7 0}$ \\
\hline 6 & Bank Danamon & $\mathbf{1 0 1 , 7 8}$ & $\mathbf{3 , 7 7}$ \\
\hline 7 & Bank Panin & $\mathbf{9 1 , 4 9}$ & $\mathbf{3 , 3 9}$ \\
\hline 8 & $\begin{array}{l}\text { Bank } \\
\text { International } \\
\text { Indonesia }\end{array}$ & $\mathbf{6 6 , 8 6}$ & $\mathbf{2 , 4 8}$ \\
\hline 9 & Bank Permata & $\mathbf{6 5 , 3 1}$ & $\mathbf{2 , 4 2}$ \\
\hline 10 & $\begin{array}{l}\text { Bank Tabungan } \\
\text { Negara }\end{array}$ & $\mathbf{6 1 , 6 6}$ & $\mathbf{2 , 2 8}$ \\
\hline
\end{tabular}

Sumber : Infobank Desember 2010

Pada tahun 2014 Bank X menargetkan pencapaian jumlah nasabah sebesar 20 juta nasabah. Nilai tersebut naik dua kali lipat dari posisi akhir 2009 sebesar 10,6 juta nasabah (Okezone.com 14/1/2010).Untuk area Riau diketahui jumlah nasabah Bank $\mathrm{X}$ pada tahun 2011 ini sudah mencapai lebih dari 400 ribu nasabah (Riau Pos 5/4/2011). Sedangkan pada tahun 2009 diketahui jumlah nasabah Bank X untuk area Pekanbaru saja berjumlah 167.924 nasabah (HR Provider Bank X Pekanbaru 2011).Untuk lebih jelasnya mengenai jumlah nasabah Bank $\mathrm{X}$ untuk area Pekanbaru di delapan Kantor Cabang dan kantor Kas pada Tahun 2009 dapat dilihat pada Tabel 2 berikut ini.
Tabel 2 : Jumlah Nasabah Bank X Area PekanbaruPer Desember 2009

\begin{tabular}{|c|l|c|}
\hline $\mathbf{P}$ & Nama Kantor Bank X & Jumlah \\
\hline 1 & HUB Sudirman Bawah & 30.232 \\
\hline 2 & HUB Sudirman Atas & 33.485 \\
\hline 3 & HUB Ahmad Yani & 64.885 \\
\hline 4 & Spoke Nangka & 15.230 \\
\hline 5 & Spoke Jl. Riau & 9.024 \\
\hline 6 & Kas Rumbai & 5.760 \\
\hline 7 & Kas Tambusai & 5.144 \\
\hline 8 & Kas Panam & 4.204 \\
\hline & Total & $\mathbf{1 6 7 . 9 6 4}$ \\
\hline
\end{tabular}

Sumber : Modul SOP, HR Provider, PT. Bank X, Tbk. Pekanbaru 2011

Semakin banyak pelanggan perusahaan, maka semakin besar pemasukan yang dapat diraih perusahaan, sebaliknya semakin sedikit pelanggan perusahaan, maka semakin sedikit pula pemasukan yang dapat diraih perusahaan. Namun hal yang harus dipahami oleh perbankan adalah semakin banyak nasabah maka bank tersebut akan semakin sulit mengenali nasabahnya secara teliti. Hal ini tentu saja akan membuat service excellence sulit dicapai dan akan menjadi alasan bagi nasabah untuk meninggalkan bank tersebut. Kita dapat menemukan bukti dari kesimpulan tersebut dengan melihat secara saksama apa yang dialami BNI pada tahun 2009. Sekitar 50\% dari nasabah yang meninggalkan BNI alasannya adalah karena layanan buruk (Roy Morgan Single Source dalam Infobanknews.com 2009). Padahal tiga tahun sebelumnya Bank Negara Indonesia merupakan yang tertinggi dalam hal customer satisfaction dari nasabah bank di Indonesia (Roy Morgan Single Source dalam Infobanknews.com 2009)

Penelitian ini memilih P.T. Bank $X$ (persero), Tbk. Pekanbaru sebagai obyek penelitian berdasarkan tiga alasan.Pertama, adanya interaksi antar departemen yang sangat padat berkaitan dengan aktivitasnya sebagai bank pembayar sehingga dapat menentukan tingkat service excellence. Kedua Bank X 
merupakan bank pemerintah sekaligus bank terbesar di Indonesia, hal ini terkait dengan persepsi masyarakat tentang pelayanan yang buruk terhadap sebagian besar instansi pemerintah yang tidak terkecuali bank pemerintah. Ketiga, Bank X merupakan peraih Best Service Excellence empat tahun berturutturut (2008，2009，2010， 2011 menurut Marketing Research Indonesia) Infobank, 2011.

\section{Rumusan Masalah}

Permasalahan yang diintisarikan dari latar belakang yang akan diuji secara mendalam melalui pertanyaan penelitian adalah :

1.Bagaimana pengaruh interaksi antar departemen terhadap service excellence ?

2.Bagaimana pengaruh sistem informasi pemasaran terhadap service excellence?

3.Bagaimana pengaruh sistem kontrol terhadap service excellence?

\section{Tujuan penelitian}

Tujuan yang hendak dicapai dalam penelitian ini adalah :

1.Menganalisis pengaruh interaksi antar departemen terhadap service excellence

2.Menganalisis pengaruh sistem informasi pemasaran terhadap service excellence

3.Menganalisis pengaruh sistem kontrol terhadap service excellence

\section{Manfaat Penelitian}

1.Memberikan kontribusi kepada dunia bisnis terutama perbankan mengenai faktor-faktor yang mempengaruhi service excellence.

2.Memberikan sumbangan terhadap pengembangan ilmu pengetahuan khususnya dibidang ilmu manajemen strategik.

3.Memberikan tambahan informasi kepada peneliti dibidang ilmu manajemen strategik khususnya mengenai penyusunan strategi yang dapat meningkatkan kinerja perbankan.

\section{Telaah Pustaka}

(Fisk et al. dalam Johnston 2004, vol 14) mengemukakan bahwa, di masa lalu banyak organisasi telah puas dengan hanya memenuhi tuntutan pelanggan mereka sedangkan kini penekanannya telah berorientasi pada pada kepuasan pelanggan. Di masa depan, Fisk berpendapat bahwa organisasi akan lebih khawatir dengan pencapaian kepuasan pelanggan. Alasan ini mungkin karena "Bukti menunjukkan bahwa pelanggan yang sekedar puas saja tidak cukup untuk mempertahankan mereka dan bahkan pelanggan yang puas pun tidak loyal pada tingkat tinggi di banyak industri "(Schneider dan Bowen et al. dalam Johnston 2004, vol 14). Perlu dicatat bahwa strategi dari memuaskan pelanggan mungkin tidak sesuai untuk semua organisasi (Johnston at al 2004).

Penelitian terdahulu yang dilakukan oleh Menon, Jaworski dan Kohli (1997, p.191) menguji hubungan interaksi antar departemen dengan service excellence, namun belum memasukkan variabel lain berupa sistem informasi pemasaran dan sistem kontrol yang menurut Beal (2000, p. 27) kedua variabel tersebut juga mempunyai pengaruh yang signifikan terhadap service excellence.

Sebagai usaha untuk mencapai kepuasan pelanggan, pihak perbankaan dapat berpedoman pada variabel service excellence yang dijelaskan oleh Barata (Barata, 2004:31) yaitu kemampuan (Ability), sikap (Attitude), penampilan (Appearance), perhatian (Attention), tindakan (Action), dan tanggung jawab (Accountability).

Dalam sebuah penelitian yang dilakukan oleh Swastika (2005) service excellence dapat diwakili oleh 6 variabel yang terdiri dari kemampuan (ability), sikap (attitude), penampilan (appearance), perhatian (attention), tindakan (action) dan tanggung jawab (accountability). Sedangkan menurut Tjiptono (2002:58) service excellence terdiri dari 4 unsur pokok, antara lain kecepatan, ketepatan, keramahan, dan kenyamanan.

\section{Metode Penelitian}


Memuat paparan jenis penelitian, subjek penelitian dan partisipan, instrumen penelitian, pengumpulan data dan metode nya, analisis data.

\section{Sumber Data}

Sumber data yang digunakan dalam penelitian ini adalah data primer dan data sekunder. Data primer yang dimaksud disini adalah data yang diperoleh secara langsung dari sumber data (Indriantoro dan Supomo 1999). Dalam penelitian ini data diperoleh secara langsung dari responden dengan cara membagikan kuesioner/daftar pertanyaan pada responden. Sementara itu kuesioner yang diajukan disusun berdasarkan variabel yang telah ditentukan. Yang menjadi data primer dalam penelitian ini adalah top manager dan middle

manager serta pegawai representatif di

PT. Bank X se Kota Pekanbaru. Sedangkan data sekunder adalah data yang diperoleh dari pihak lain dalam bentuk yang sudah jadi berupa publikasi. Dalam hal ini data sekunder berupa hasil laporan kegiatan dan data jumlah pegawai Bank X se-Kota Pekanbaru.

\section{Populasi dan Sampel}

Jumlah keseluruhan dari unit analisis yang ciri-cirinya akan diduga sebagai obyek penelitian dari penelitian ini, atau yang juga sering disebut dengan populasi (Indriantoro dan Supomo 1999), dalam penelitian ini adalah top manager dan middle manager serta pegawai representatif di PT. Bank X se-Kota Pekanbaru atau mereka yang secara langsung terlibat dalam upaya memberikan pelayanan pada nasabah. Sebab hal ini terkait dengan isu kualitas pelayanan dan kepuasan pelanggan yang menjadi focus utama dalam penelitian ini. Populasi top manager dan middle manager serta pegawai representatif di PT. Bank X se-Kota Pekanbaru berjumlah 102 orang

Responden yang digunakan dalam penelitian ini adalah keseluruhan dari populasi yang ada. Hal ini disebabkan karena pertimbangan masalah respon rate (tingkat kembalian) kuesioner yang dibagikan kepada

responden yang akan diteliti. Dengan demikian teknik pengambilan sampel yang digunakan dalam penelitian ini adalah metode sensus, yaitu teknik pengambilan sampel yang dilakukan keseluruhan jumlah populasi yang ada.

Alasan lain dari pengambilan sampel dengan melibatkan keseluruhan dari populasi ini mengacu pada ketentuan dari Hair,et al (1995) yang berpendapat bahwa jumlah sampel yang representatif adalah sekitar 100-200. Disamping itu jumlah ini juga telah memenuhi kriteria jumlah sampel yang berpedoman pada ketentuan bahwa jumlah sampel yang representatif adalah 5-10 kali jumlah parameter yang digunakan (Hair, et al 1995). Sebab dengan jumlah indikator 12 x 8 maka jumlah sampel yang representatif yang direkomendasikan untuk

\begin{tabular}{|c|c|c|c|c|}
\hline $\begin{array}{l}\text { Nama } \\
\text { Kantor }\end{array}$ & Jabatan Responden & $\begin{array}{l}\text { Juml } \\
\text { ah } \\
\text { Kant } \\
\text { or } \\
(\mathrm{JK})\end{array}$ & $\begin{array}{l}\text { Jumla } \\
\text { h } \\
\text { Respo } \\
\text { nden } \\
\text { (JR) }\end{array}$ & $\begin{array}{l}\text { Total } \\
\text { Respo } \\
\text { nden } \\
\text { (JK X } \\
\text { JR) }\end{array}$ \\
\hline $\begin{array}{c}\text { Kantor } \\
\text { Wilaya } \\
\text { h }\end{array}$ & $\begin{array}{l}\text { Area Manajer, } \\
\text { Marketing } \\
\text { Officer,Operational } \\
\text { manajer, Officer }\end{array}$ & 1 & $\begin{array}{l}1+5 \\
+1+5 \\
=12\end{array}$ & 12 \\
\hline $\begin{array}{l}\text { Caban } \\
\text { g Hub }\end{array}$ & $\begin{array}{l}\text { HUB Manajer, Hub } \\
\text { Outlet Manajer, } \\
\text { Comercial Manajer, } \\
\text { Relationship } \\
\text { Manajer, CS } \\
\text { Representatif, CS } \\
\text { Officer, Head Teller }\end{array}$ & 3 & $\begin{array}{l}1+2+ \\
2+3+ \\
5+4+ \\
1 \\
=18\end{array}$ & 54 \\
\hline $\begin{array}{l}\text { Caban } \\
\text { g } \\
\text { Spoke }\end{array}$ & $\begin{array}{l}\text { Spoke Manajer, CS } \\
\text { Officer, CS } \\
\text { Representatif, } \\
\text { Comercial Manajer, } \\
\text { Head Teller }\end{array}$ & 3 & $\begin{array}{l}1+2+ \\
2+1+ \\
1=7\end{array}$ & 21 \\
\hline $\begin{array}{l}\text { Mandi } \\
\text { ri } \\
\text { Priorit } \\
\text { as }\end{array}$ & $\begin{array}{l}\text { Comercial Manajer, } \\
\text { CS Officer, } \\
\text { CS Representatif, } \\
\text { Head Teller }\end{array}$ & 1 & $\begin{array}{l}1+2+ \\
2+1 \\
=6\end{array}$ & 6 \\
\hline $\begin{array}{c}\text { Kantor } \\
\text { kas }\end{array}$ & $\begin{array}{l}\text { Cash Outlet } \\
\text { Manajer, CS Officer } \\
\text { CS Representatif }\end{array}$ & 3 & $\begin{array}{l}1+1 \\
+1 \\
=3\end{array}$ & 9 \\
\hline & Total & 12 & & 102 \\
\hline
\end{tabular}


penelitian ini adalah 96.

Tabel 3 : Daftar Sensus Responden Sumber : Modul SOP, HR Provider, PT. Bank X, Tbk. Pekanbaru 2011

\section{Metode Pengumpulan Data}

Pengumpulan data dilakukan dengan menggunakan kuesioner yaitu suatu metode pengumpulan data dengan memberikan atau menyebarkan daftar pertanyaan kepada responden.

\section{Metode Analisis Data}

Berkaitan dengan usaha penganalisaan tersebut, penulis menggunakan metode:

\section{Deskriptif}

Yaitu dengan menginventarisasi datadata yang diperlukan berupa kuesioner lalu memberikannya secara menyeluruh kepada responden, kemudian menganalisa data tersebut berdasarkan teori.

2. Kuantitatif

Dalam hal ini, penulis mencoba menyusun alat ukur untuk menguji kebenaran hipotesis yang telah dikemukakan dengan cara mengukur tingkat hubungan atau korelasi antara variabel terikat dengan variable bebas.

Pada penelitian ini menggunakan skala likert dimana variabel akan diukur atau dijabarkan menjadi indikator variabel seperti yang telah dijelaskan pada teknik pengumpulan data. Kemudian indikator tersebut dijadikan sebagai titik tolak untuk menyusun item - item instrumen berupa pernyataan. Namun karena jawaban dari pernyataan tersebut bersifat kualitatif, maka data yang sifatnya kualitatif tersebut akan diberi skor hingga menjadi kuantitatif, untuk setiap jawaban diberi nilai berdasarkan lima alternatif dengan ketentuan sebagai berikut :

-Untuk jawaban Sangat Baik diberi nilai 5

-Untuk jawaban Baik diberi nilai 4

-Untuk jawaban Cukupdiberi nilai 3

-Untuk jawaban Tidak Baik diberi nilai 2

-Untuk jawaban Sangat Tidak Baikdiberi nilai 1
Sebelum melakukan analisis regresi dilakukan pengolahan data dengan mengubah data ordinal menjadi data interval dengan menggunakan Metode Suksesif Interval (MSI). MSI berfungsi untuk mengubah skala ordinal menjadi skala interval, Hayes (1969) dalam Sukawati (2007 : 75). Suatu daftar pernyataan yang dijawab dengan pendekatan skala likert akan menghasilkan data ordinal yang tidak menunjukkan perbandingan suatu jawaban secara nyata. Dengan data interval perbandingan antar jawaban yang sebenarnya akan terlihat tajam sehingga dapat diolah untuk memperoleh nilai jawaban responden

Data ordinal yang diperoleh kemudian di transformasikan ke data interval dengan menggunakan langkah-langkah dalam MSI (Method of Successive Interval) adalah sebagai berikut :

1.Perhatikan setiap butir jawaban responden dari angket yang disebarkan.

2.Pada setiap butir ditentukan berapa orang yang mendapat skor 1,2,3,4 dan 5 yang disebut sebagai frekuensi.

3.Setiap frekuensi dibagi dengan banyaknya responden dan hasilnya disebut dengan proporsi

4.Tentukan nilai proporsi kumulatif dengan jalan menjumlahkan nilai proporsi secara berurutan perkolom skor.

5. Gunakan tabel distributor normal, hitung tabel $\mathrm{Z}$ untuk setiap proporsi kumulatif yang peroleh.

6.Tentukan nilai tinggi densitas untuk setiap nilai $\mathrm{Z}$ yang diperoleh (dengan menggunakan tabel tinggi densitas)

7.Tentukan nilai skala dengan menggunakan rumus :

NS $=$ ( Densitiy at lower limit ) (Density at upper limit) .

( Area below upper limit ) ( Area below lower limit)

8. Tentukan nilai transformasi dengan rumus :

$$
\begin{aligned}
\mathrm{Y}= & \mathrm{NS}+[1+\mathrm{NSmin} \\
& \text { Untuk menentukan skala penilaian }
\end{aligned}
$$


digunakan rumus rentang skala sbb :

$$
\begin{gathered}
\text { ( Umar, } 2002: 44) \\
\mathrm{RS}=\mathrm{n}(\mathrm{m}-1) \\
\mathrm{Ms}
\end{gathered}
$$

RS $=$ Rentang Skala

$\mathrm{n}=$ Jumlah sampel

$\mathrm{m}=$ Jumlah alternatif jawaban tiap item

Jumlah responden $=102$ Orang

Jumlah alternatif jawaban $=5$

Kemungkinan nilai tertinggi : (102 (5-1)) $/ 5=$ 81,6 dibulatkan menjadi 82

Maka didapat rentang skala sebagai berikut :

$102-184=$ Sangat Tidak baik

$185-266=$ Tidak baik

$267-348=$ Cukup

$349-430=$ baik

$431-510=$ Sangat baik

Untuk menganalisis pengaruh variabel bebas terhadap variabel terikat digunakan statistik inferensial yaitu analisis regresi berganda.

\begin{tabular}{|c|c|c|c|c|}
\hline & $\begin{array}{c}\text { SCALE } \\
\text { MEAN IF } \\
\text { ITEM } \\
\text { DELETE } \\
D\end{array}$ & $\begin{array}{c}\text { SCALE } \\
\text { VARIANCE } \\
\text { IF ITEM } \\
\text { DELETED }\end{array}$ & $\begin{array}{c}\text { CORRECT } \\
\text { ED ITEM- } \\
\text { TOTAL } \\
\text { CORRELA } \\
\text { TION }\end{array}$ & $\begin{array}{c}\text { CRONBAC } \\
H^{\prime} S \text { ALPHA } \\
\text { IF ITEM } \\
\text { DELETED }\end{array}$ \\
\hline $\begin{array}{l}\text { VAR0000 } \\
1\end{array}$ & 44.7000 & 74.286 & .764 & .952 \\
\hline $\begin{array}{l}\text { VAROOOOO } \\
2\end{array}$ & 44.7667 & 74.116 & .811 & .950 \\
\hline $\begin{array}{l}\text { VAROOOOO } \\
3\end{array}$ & 44.6667 & 72.851 & .778 & .951 \\
\hline $\begin{array}{l}\text { VAROOOO } \\
4\end{array}$ & 44.9333 & 74.547 & .813 & .950 \\
\hline $\begin{array}{l}\text { VARO000 } \\
5\end{array}$ & 44.8333 & 75.040 & .744 & .952 \\
\hline $\begin{array}{l}\text { VAR0000 } \\
6\end{array}$ & 44.9333 & 74.616 & .663 & .955 \\
\hline $\begin{array}{l}\text { VAR0OOO } \\
7\end{array}$ & 44.6000 & 71.352 & .889 & .948 \\
\hline $\begin{array}{l}\text { VAROOOO } \\
8\end{array}$ & 44.7333 & 70.685 & .818 & .950 \\
\hline $\begin{array}{l}\text { VAR0000 } \\
9\end{array}$ & 44.5333 & 73.706 & .822 & .950 \\
\hline $\begin{array}{l}\text { VAR0001 } \\
0\end{array}$ & 44.7667 & 70.806 & .770 & .952 \\
\hline $\begin{array}{l}\text { VAR0001 } \\
1\end{array}$ & 44.6667 & 73.816 & .747 & .952 \\
\hline $\begin{array}{l}\text { VAR0001 } \\
2\end{array}$ & 44.6667 & 72.161 & .791 & .951 \\
\hline
\end{tabular}
Adapun model regresi yang digunakan dalam
ITEM-TOTAL STATISTICS

mengestimasi variabel terikat dengan prediktor empat variabel bebas dalam penelitian ini yaitu :

$\mathrm{Y}=\mathrm{B} 0+\mathrm{B} 1 \mathrm{X} 1+\mathrm{B} 2 \mathrm{X} 2+\mathrm{B} 3 \mathrm{X} 3+\mathrm{e}$

Dimana:

$\mathrm{Y}=$ Service Excellence;

$\mathrm{X} 1$ = Interaksi Antar Departemen; X2 = Sistem Informasi Pemasaran; X3 = Sistem Kontrol; Bo = Konstanta;

$\mathrm{B} 1 \ldots \mathrm{B} 3=$ Koefisien regresi $\mathrm{X} 1$; $\mathrm{X} 2$; X3 ;

$\mathrm{e}=$ error terms

Pengujian hipotesis digunakan uji $\mathrm{F}$ untuk menguji ada/tidaknya pengaruh yang signifikan antara variabel bebas terhadap variabel terikat secara simultan dan uji $t$ untuk 
menguji ada/tidaknya pengaruh yang signifikan antara variabel bebas terhadap variabel terikat secara parsial.

Selanjutnya untuk membuktikan kebenaran hipotesis digunakan uji kelayakan secara total dengan menggunakan uji $\mathrm{F}$ yakni dengan membandingkan $\mathrm{F}$ hitung dengan $\mathrm{F}$ tabel. Jika $\mathrm{F}$ hitung > F tabel, maka terdapat hubungan antara variabel bebas dan variabel terikat.

Selain itu juga dilakukan pembuktian kebenaran hipotesis secara parsial yakni dengan melakukan uji $t$, dengan membandingkan $t$ hitung dengan $t$ tabel pada tingkat signifikan $=$ 0,05 . Jika $t$ hitung $>t$ tabel artinya variabel bebas menerangkan variabel terikat, dan berarti adanya pengaruh diantara 2 variabel yang diteliti.

Uji koefisien determinasi $\left(\mathrm{R}^{2}\right)$ yaitu pengujian kontribusi pengaruh dari semua variabel bebas ( dependen ) secara bersama sama terhadap variabel terikat ( dependen ), apabila nilai $\mathrm{R}^{2}$ semakin mendekati 1 merupakan indikator yang nenunjukkan semakin kuatnya pengaruh variabel - variabel $\mathrm{X}$ terhadap variabel berikutnya.

\section{Hasil dan Pembahasan}

\section{Uji Validitas dan Uji Reliabilitas}

Berikut penulis sajikan hasil uji validitas dan reliabilitas dari kuesioner yang disebarkan kepada 30 responden.

Tabel. 4 Uji Validitas dan Reliabilitas X1, X2, $\mathrm{X3,dan} Y$ untuk 30 responden

Sumber : Data Olahan Hasil Penelitian Tahun 2011

\begin{tabular}{|r|r|}
\multicolumn{2}{|c|}{ Reliability Statistics } \\
$\begin{array}{r}\text { CRONBACH'S } \\
\text { AlPhA }\end{array}$ & NOF ItEMS \\
\hline .955 & 12 \\
\hline
\end{tabular}

Hasil analisis untuk 30 responden diatas, nampak pada kolom corrected item correlation nilai uji validitas untuk variabel $\mathrm{X} 1$ yang terdiri dari indikator $\mathrm{X} 1.1, \quad \mathrm{X} 1.2, \quad \mathrm{X} 1.3$ ternyata semuanya valid karena nilai ujinya > 0.30 , sehingga input data yang digunakan dalam analisis melibatkan semua indikator X1. Pada kolom corrected item correlation nilai uji validitas untuk variabel X2 yang terdiri dari indikator X2.1, X2.2, X2.3 ternyata semuanya valid karena nilai ujinya $>0.30$, sehingga input data yang digunakan dalam analisis melibatkan semua indikator X2. Begitu juga pada kolom corrected item correlation nilai uji validitas untuk variabel X3 yang terdiri dari indikator $\mathrm{X} 3.1, \mathrm{X} 3.2, \quad \mathrm{X} 3.3$ ternyata semuanya valid karena nilai ujinya $>0.30$, sehingga input data yang digunakan dalam analisis dataa melibatkan semua indikator X3. Nilai reliabilitas dari alpha cronbach's menunjukkan nilai 0.955 . Hal ini menunjukkan seluruh indikator variabel penelitian X1, X2, X3 dan Y dinyatakan reliabel. Dengan demikian maka indikator-indikator tersebut dapat digunakan pada objek yang berbeda dengan kesempatan yang berbeda pula.

\section{Uji Asumsi Klasik}

Pengujian asumsi klasik diperlukan untuk mengetahui apakah hasil estimasi regresi yang dilakukan benar-benar bebas dari adanya gejala multikolinieritas, gejala heterokedastisitas, gejala autokorelasi dan normalitas suatu data.

\section{Uji Multikolinieritas}

Uji multikolinieritas merupakan uji yang ditunjukkan untuk menguji apakah model regresi ditemukan adanya korelasi antar variabel bebas (variabel independen). Model uji regresi yang baik selayaknya tidak terjadi multikolinieritas.

\section{Tabel 5 :Uji Multikolinieritas berdasar VIF}

\begin{tabular}{|l|l|l|}
\hline \multirow{2}{*}{ Model } & \multicolumn{2}{|l|}{ Collinearity Statistics } \\
\cline { 2 - 3 } & Tolerance & VIF \\
\hline 1 (constant) & & \\
$X 1$ & .873 & 1.146 \\
$X 2$ & .861 & 1.162 \\
$X 3$ & .965 & 1.036 \\
\hline
\end{tabular}


Sumber : Data Olahan Hasil Penelitian Tahun 2011

Berdasarkan Tabel 5 diketahui nilai VIF X1 sebesar 1.146, VIF X2 sebesar 1.162 dan VIF $\mathrm{X} 3$ sebesar 1.036 yang mana nilai ketiga variabel tersebut < 10. Dengan demikian dapat disimpulkan bahwa tidak terjadi multikolinieritas dalam penelitian ini.

\section{Tabel 6 : Uji Multikolinieritas Berdasar Eigenvalue}

Berdasarkan Tabel 6 pada kolom model 1 diketahui nilai eigenvalue sebesar 3.884. Ini menunjukkan tidak ada pengeluaran variabel bebas karena nilai eigenvalue tersebut jauh diatas nilai 0 (nol).

\section{Uji Autokorelasi}

Tujuan uji autokorelasi adalah menguji tentang ada tidaknya korelasi antara kesalahan pengganggu pada periode $t$ dengan perriode $t-1$ pada persamaan regresi linear. Apabila terjadi korelasi maka menunjukkan adanya problem autokorelasi.Model regresi yang baik adalah yang bebas autokorelasi. Salah satu cara untuk mendeteksi aoutokorelasi adalah dengan Uji Durbin Watson.

Tabel 7 : Uji Autokorelasi berdasarkan Durbin Watson

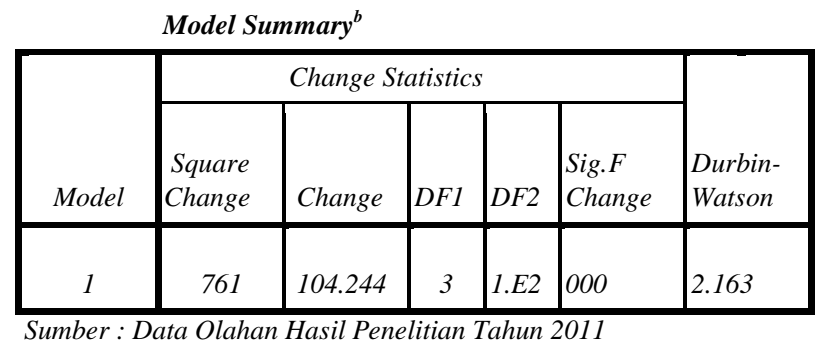

Pembahasan hasil uji Durbin Watson sebagai berikut :

1. Menentukan Hipotesis

H0 : tidak ada autokorelasi

H1 : ada autokorelasi

2. Menentukan nilai alpha dengan $d$ tabel $(n, k)$ terdiri atas dl dan du, dl $(\mathrm{n}=102, \mathrm{k}=3)=$ $1.6174 ; \mathrm{du}(\mathrm{n}=102, \mathrm{k}=3)=1.7383$

3. Hasil

Nilai DW $(2.163)>d u(1.7383)$
Kesimpulannya tidak ada autokorelasi.

\section{Uji Heteroskedastisitas}

Heterokedastisitas menunjukkan bahwa varians variabel tidak sama untuk semua pengamatan. Jika varian dari residual satu pengamatan ke pengamatan yang lain tetap, maka disebut homoskedastisitas. Model regresi yang baik adalah yang homoskedastisitas atau tidak terjadi heteroskedastisitas.

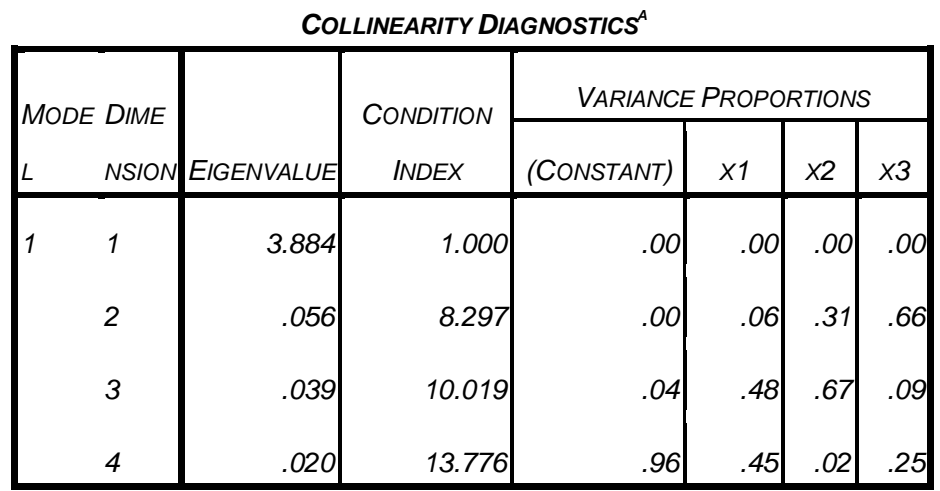

A. DePENDENT VARIABlE: Y Sumber : Data Olahan Hasil Penelitian Tahun 2011

\section{Gambar 1 : Uji Heteroskedastisitas}

Scatterplot

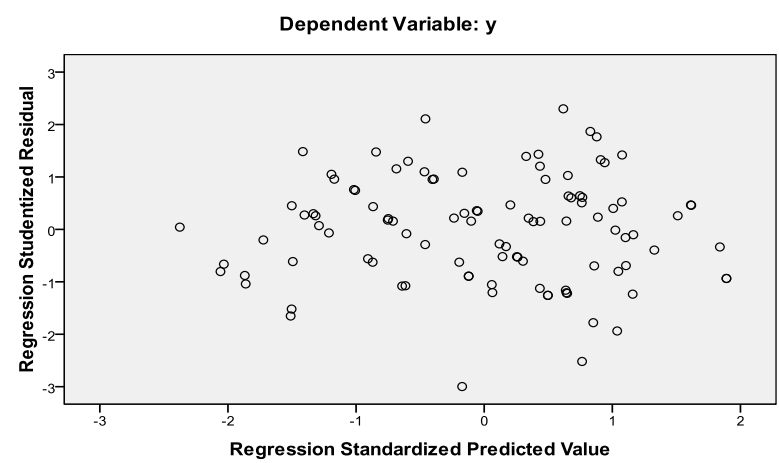

Sumber : Data Olahan Hasil Penelitian Tahun 2011

Dengan melihat penyebaran titik-titik yang acak baik di atas maupun dibawah angka 0 (nol) dari sumbu $\mathrm{Y}$ dapat disimpulkan tidak terjadi heteroskedastisitas dalam model regresi ini.

\section{Uji Normalitas}

Uji normalitas dilakukan untuk melihat apakah dalam model regresi variabel terikat dan variabel bebas keduanya mempunyai distribusi normal ataukah tidak. Model regresi yang baik 
adalah model regresi yang berdistribusi normal.

Gambar 2 : Uji Normalitas Dalam Bentuk Histogram

Coefficients $^{a}$

\begin{tabular}{|c|c|c|c|c|c|c|c|c|}
\hline \multirow[b]{2}{*}{ Model } & \multicolumn{2}{|c|}{\begin{tabular}{|l|} 
Unstandardized \\
Coefficients
\end{tabular}} & \multirow{2}{*}{$\begin{array}{l}\begin{array}{l}\text { Standardized } \\
\text { Coefficients }\end{array} \\
\text { Beta }\end{array}$} & \multirow[b]{2}{*}{$t$} & \multirow[b]{2}{*}{ Sig. } & \multicolumn{3}{|c|}{ Correlations } \\
\hline & $B$ & Std. Error & & & & $\begin{array}{l}\text { Zero- } \\
\text { order }\end{array}$ & $\begin{array}{l}\text { Parti } \\
\text { al }\end{array}$ & Part \\
\hline \begin{tabular}{|ll}
$\begin{array}{l}\text { (Const } \\
\text { ant })\end{array}$ \\
\end{tabular} & .230 & .180 & & 1.277 & .205 & & & \\
\hline$x 1$ & .292 & .047 & .329 & 6.223 & .000 & .549 & .532 & .307 \\
\hline$x 2$ & .377 & .044 & .457 & 8.585 & .000 & .654 & .655 & .424 \\
\hline$x 3$ & .394 & .042 & .474 & 9.445 & .000 & .595 & .690 & .466 \\
\hline
\end{tabular}

a. Dependent Variable: ySumber : Data Olahan Hasil Penelitian Tahun 2011

Histogram

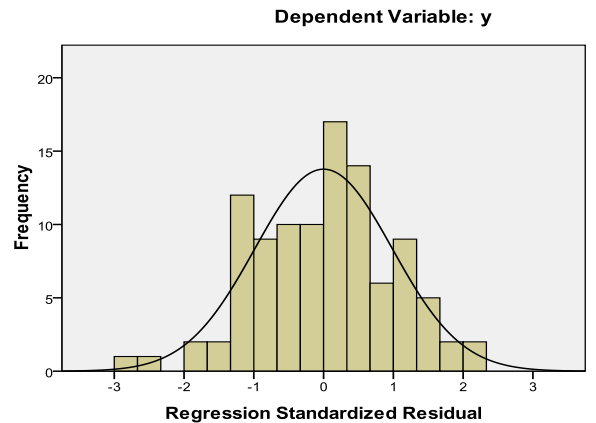

Sumber : Data Olahan Hasil Penelitian Tahun 2011

Output histogram menunjukkan pola distribusi yang normal karena sisi kiri dan kanan histogram hampir sama dan data secara pasti berdistribusi antara -3 sampai dengan 3 dan tidak ada data yang berada diluar kurva.

\section{Gambar 3 : Uji Normalitas Dalam Bentuk Grafik} Normal P-P Plot of Regression Standardized
Residual

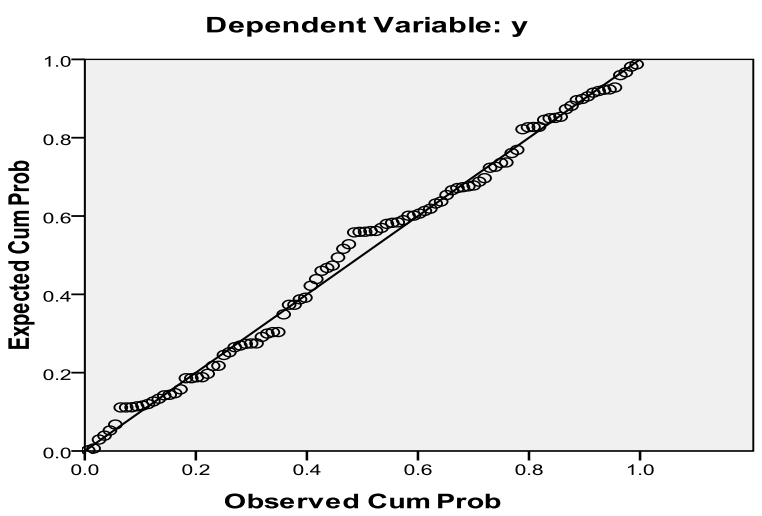

Sumber : Data Olahan Hasil Penelitian Tahun 2011

Output grafik menunjukkan pola penyebaran titik-titik disekitar garis diagonal dan mengikuti arah garis diagonal sehingga mengindikasikan model regresi memenuhi asumsi normalitas.

\section{Analisis Persamaan Regresi Linear Berganda}

Analisis ini digunakan untuk mengetahui seberapa besar pengaruh variabel independent (bebas) yang terdiri dari interaksi antar departemen (X1), sistem informasi pemasaran (X2) dan sistem kontrol (X3) terhadap variabel dependent (terikat) yaitu service excellence $(\mathrm{Y})$ baik secara bersama-sama maupun sendirisendiri.

\section{Tabel 8 : Persamaan Regresi Linear Berganda}

Hasil pengujian pada tabel 8 menunjukkan nilai koefisien regresi masingmasing variabel X1, X2 dan X3. Pada tabel tersebut menunjukkan nilai beta nol adalah 0.230 (a), nilai beta satu adalah 0.292(b1), nilai beta dua adalah $0.377(\mathrm{~b} 2)$ dan nilai beta tiga adalah 0.394(b3). Berdasaarkan hasil pengujian tersebut dapat disusun persamaan regresi berganda sebagai berikut :

$$
\begin{aligned}
& \mathrm{Y}=\mathrm{a}+\mathrm{b} 1 . \mathrm{X} 1+\mathrm{b} 2 . \mathrm{X} 2+\mathrm{b} 3 . \mathrm{X} 3+\mathrm{e} \\
& \mathrm{Y}=0.230+0.292 \mathrm{X} 1+0.377 \mathrm{X} 2+
\end{aligned}
$$

\section{$0.394 \times 3+e$}

Persamaan regresi diatas digunakan sebagai alat memprediksi dan mengevaluasi 
kecenderungan keputusan memilih berdasarkan asumsi apabila salah satu variabel bebasnya dikendalikan :

a. Nilai $\mathrm{a}=0.230$ merupakan nilai konstanta yang apabila nilai seluruh variabel dianggap nol, maka nilai service excellence sebesar 0.230 satuan.

b. Nilai b1 $=0.292$ merupakan koefisien regresi untuk interaksi antar departemen (X1), menunjukkan apabila variabel interaksi antar departemen (X1) ditingkatkan satu satuan maka akan terjadi peningkatan pada Y sebesar 0.292 satuan. Koefisien bersifat positif artinya terdapat hubungan positif antara interaksi antar departemen dengan service excellence.

c. Nilai b2 $=0.377$ merupakan koefisien regresi untuk sistem informasi pemasaran (X2), menunjukkan apabila variabel sistem informasi pemasaran (X2) ditingkatkan satu satuan maka akan terjadi peningkatan pada $\mathrm{Y}$ sebesar 0.377 satuan. Koefisien bersifat positif sehingga terdapat hubungan positif antara sistem informasi pemasaran dengan service excellence

d. Nilai b3 $=0.394$ merupakan koefisien regresi untuk sistem kontrol (X3), menunjukkan apabila variabel sistem kontrol (X3) ditingkatkan satu satuan maka akan terjadi peningkatan pada $\mathrm{Y}$ sebesar 0.394 satuan. Koefisien bersifat sehingga terdapat hubungan positif antara sistem kontrol dengan service excellence.

\section{Pengujian Koefisien Determinasi ( $\mathbf{R}^{2}$ )}

Untuk melihat pengaruh interaksi antar departemen, sistem informasi pemasaran dan sistem kontrol terhadap service excellence, maka kita akan melihat perhitungan dalam tabel model summary pada tabel 9 berikut.

Tabel 9 : Uji Koefisien Determinasi Berdasarkan Model Summary

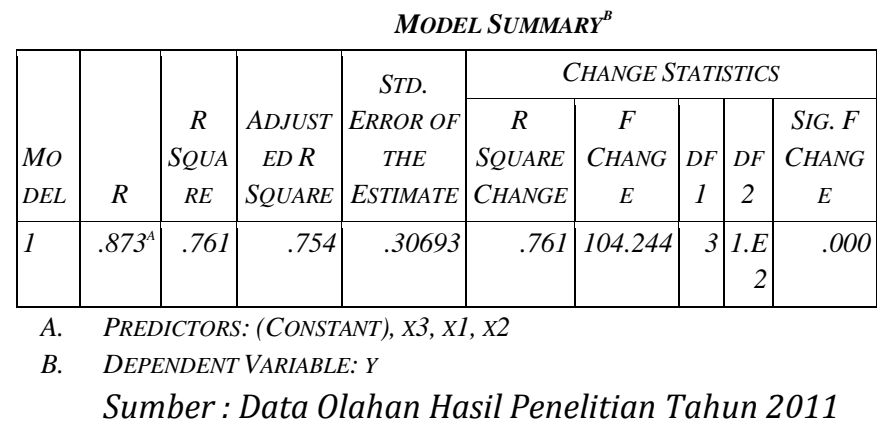

Tabel model summary menggambarkan hubungan kausalitas ( sebab akibat ) antara X1, $X 2$ dan X3 dengan variabel $Y$. Nilai $R$ digunakan untuk mengukur tingkat keeratan korelasional antara variabel dependen (Y) dengan variabel independent $(\mathrm{X} 1, \mathrm{X} 2, \mathrm{X} 3)$ yaitu sebesar 0,873. Hal ini memberikan indikasi bahwa keeratan hubungan antara variabel dependent dengan variabel independent adalah positif dan sangat kuat karena mendekati 1 yaitu 0,873 . Ini berarti bahwa interaksi antar departemen (X1), sistem informasi pemasaran (X2) dan sistem kontrol (X3) secara bersamasama mempunyai pengaruh yang signifikan terhadap variabel service excellence $(\mathrm{Y})$.

Besarnya koefisien determinasi $\mathrm{R}$ square $\left(\mathrm{R}^{2}\right.$ ) dapat digunakan untuk melihat besarnya persentase pengaruh interaksi antar departemen, sistem informasi pemasaran dan sistem kontrol terhadap service excellence di Bank X. Dari tabel model summary (lihat table 9) dapat dilihat $\mathrm{R}$ square yang dihasilkan sebesar 0,761 atau $76,1 \%$. Ini menunjukkan bahwa persentase pengaruh variabel independen (interaksi antar departemen, sistem informasi pemasaran dan sistem kontrol) terhadap variabel dependen (service excellence) sebesar 76,1\%. Sedangkan sisanya yaitu $23,9 \%$ dipengaruhi oleh variabel lain yang yang tidak termasuk dalam penelitian ini.

\section{Pengujian Signifikansi Serentak atau Simultan ( Uji-F ) \\ Tabel 10 : Analisis Varian (ANOVA) untuk Uji-F}




\begin{tabular}{|l|c|c|c|c|c|}
\hline MODEL & $\begin{array}{c}\text { SUM OF } \\
\text { SQUARE } \\
\text { S }\end{array}$ & DF & $\begin{array}{c}\text { MEAN } \\
\text { SQUAR }\end{array}$ & F & F \\
\hline $\begin{array}{l}\text { IREGRE } \\
\text { SSION }\end{array}$ & 29.461 & 3 & 9.820 & 104.244 & $.000^{4}$ \\
RESIDU & 9.232 & 98 & .094 & & \\
AL & & & & & \\
TOTAL & 38.693 & 101 & & & \\
\hline
\end{tabular}

A. PREDICTORS: (CONSTANT), X3, X1, X2

\section{B. DEPENDENT VARIABLE: $Y$}

\section{Sumber:Data Olahan Hasil Penelitian Tahun} 2011

Dari tabel diatas dilihat bahwa $\mathrm{F}$ hitung yang diperoleh adalah 104.244, hal ini menunjukkan bahwa $\mathrm{F}$ hitung yang sebesar 104.244 dengan signifikansi sebesar $0,000 \alpha$ tersebut ternyata lebih besar dari $\mathrm{F}$ tabel .

Cara mencari $\mathrm{F}$ tabel dengan tingkat keyakinan $5 \%$, dengan perhitungan :

$$
\begin{aligned}
\mathrm{F} \alpha & =(\mathrm{k}-1) ;(\mathrm{n}-\mathrm{k}) \\
& =3-1 ; 102-3 \\
& =2 ; 99 \\
& =3,088
\end{aligned}
$$

Maka dengan demikian terlihat bahwa $\mathrm{F}$ hitung > F tabel atau 104.244 > 3.088 sehingga dapat disimpulkan bahwa terdapat pengaruh positif dan signifikan antara variabel interaksi antar departemen, variabel sistem informasi pemasaran dan variabel sistem kontrol terhadap variabel service excellence.

Berdasarkan hasil analisis diatas maka dapat disimpulkan bahwa hipotesis yang menyebutkan bahwa variabel interaksi antar departemen, sistem informasi pemasaran dan sistem kontrol diduga mempunyai pengaruh yang signifikan terhadap service excellence di Bank X Pekanbaru dapat diterima.

\section{Pengujian Signifikan Individual atau Parsial ( Uji-t)}

Tabel 11 : Analisis Koefisien Pengujian Parsial

\begin{tabular}{|l|c|c|c|c|}
\hline \multicolumn{1}{|c|}{ Variabel } & beta & $\begin{array}{c}\mathrm{t} \\
\text { hitung }\end{array}$ & $\mathrm{t}$ tabel & Sig \\
\hline $\begin{array}{l}\text { Interaksi Antar } \\
\text { Departemen } \\
(\mathrm{X} 1)\end{array}$ & .329 & 6.223 & 1,983 & .000 \\
\hline $\begin{array}{l}\text { Sistem } \\
\text { Informasi } \\
\text { Pemasaran } \\
\text { (X2) }\end{array}$ & .457 & 8.585 & 1,983 & .000 \\
\hline $\begin{array}{l}\text { Sistem Kontrol } \\
\text { (X3) }\end{array}$ & .474 & 9.445 & 1,983 & .000 \\
\hline
\end{tabular}

Sumber : Data Olahan Hasil Penelitian Tahun 2011

Uji t dilakukan dengan membandingkan $t$ hitung dengan $t$ tabel dimana hasil perhitungan $\mathrm{t}$ tabel dengan tingkat signifikan $5 \%$, diperoleh dengan cara :

$=(\alpha / 2) ;(n-2)$

$=0,05 / 2 ; 102-2$

$=0,025 ; 100$

$=1,983$

Dari tabel 11 diatas diperoleh hasil pengujian parsial variabel bebas sebagai berikut : 1.Variabel interaksi antar departemen (X1), menunjukkan $\mathrm{t}$ hitung sebesar $6.223>$ dari $\mathrm{t}$ tabel 1,983 dengan nilai signifikan 0,000 yang kecil dari taraf signifikan $5 \%$, maka secara parsial ada pengaruh yang kuat antara variabel interaksi antar departemen dengan service excellence. Dengan nilai beta sebesar 0.329 memberikan makna bahwa interaksi antar departemen mampu memberikan sumbangsih pengaruh terhadap service excellence sebesar 0.329 satuan jika faktor lain dianggap tetap.

2.Variabel sistem informasi pemasaran (X2), menunjukkan t hitung sebesar $8.585>$ dari t tabel 1,983 dengan nilai signifikan 0,000 yang kecil dari taraf signifikan $5 \%$, maka secara parsial ada pengaruh yang kuat antara variabel sistem informasi pemasaran dengan service excellence. Dengan nilai beta sebesar 0.457 memberikan makna bahwa sistem informasi pemasaran mampu memberikan sumbangsih pengaruh terhadap service excellence sebesar 0.457 satuan jika faktor lain dianggap tetap. 
3.Variabel sistem kontrol (X3), menunjukkan t hitung sebesar $9.445>$ dari t tabel 1,983 dengan nilai signifikan 0,000 yang kecil dari taraf signifikan $5 \%$, maka secara parsial ada pengaruh yang kuat antara variabel sistem kontrol dengan service excellence. Dengan nilai beta sebesar 0.474 memberikan makna bahwa sistem kontrol mampu memberikan sumbangsih pengaruh terhadap service excellence sebesar 0.474 satuan jika faktor lain dianggap tetap.

Dari hasil pengujian parsial variabel bebas diatas diketahui bahwa ke tiga variabel bebas tersebut mempunyai pengaruh yang kuat terhadap variabel terikat. Dan daripada itu juga diketahui bahwa variabel "sistem kontrol" memiliki pengaruh paling kuat terhadap service excellence di Bank X Pekanbaru.

\section{Pengujian Hipotesis dan Pembahasan}

\section{Pengaruh Interaksi Antar Departemen terhadap Service Excellence}

Hipotesis yang diajukan dalam penelitian ini adalah :

H1 : Interaksi antar departemen berpengaruh positif dan signifikan terhadap service excellence.

Untuk menguji hipotesis yang diajukan, kita akan melihat uji $\mathrm{t}$ seperti yang sudah dilakukan sebelumnya dimana diketahui t hitung sebesar $6.223>$ dari $t$ tabel 1,983 yang berarti bahwa secara parsial ada pengaruh yang kuat antara variabel interaksi antar departemen dengan service excellence. Nilai beta diketahui sebesar 0.329 yang berarti bahwa interaksi antar departemen mampu memberikan sumbangsih pengaruh terhadap service excellence sebesar 0.329 satuan jika faktor lain dianggap tetap.

Berdasarkan hasil pengujian hipotesis, maka diperoleh hasil bahwa interaksi antar departemen (X1) berpengaruh langsung terhadap service excellence (Y). Hal ini berarti bahwa setiap perubahan yang terjadi pada interaksi antar departemen akan mengakibatkan perubahan pada service excellence yang dicapai, dimana semakin tinggi interaksi antar departemen akan semakin meningkatkan service excellence yang dicapai oleh manajemen Bank $\mathrm{X}$ dan begitu juga sebaliknya.

Hasil pengujian hipotesis ini membuktikan bahwa hipotesis 1 diterima secara signifikan. Dengan demikian, dapat dikatakan bahwa terdapat hubungan positif antara interaksi antar departemen terhadap service excellence. Hal ini mengindikasikan bahwa interaksi antar departemen mempunyai peranan yang cukup besar dalam menciptakan service excellence. Hasil penelitian ini mendukung penelitian sebelumnya yang dilakukan oleh Kohli dan Jaworski et al (1990, p.9) dan Gupta, Raj dan Wilemon (1997, p.187) yang menemukan adanya pengaruh positif antara interaksi antar departemen dengan service excellence.

\section{Pengaruh Sistem Informasi Pemasaran terhadap Service Excellence}

Hipotesis yang diajukan dalam penelitian ini adalah :

H2 : Sistem informasi pemasaran berpengaruh positif dan signifikan terhadap service excellence.

Untuk menguji hipotesis yang diajukan, kita akan melihat uji $\mathrm{t}$ seperti yang sudah dilakukan sebelumnya dimana diketahui t hitung sebesar $8.585>$ dari t tabel 1,983, hal ini berarti bahwa secara parsial ada pengaruh yang kuat antara variabel sistem informasi pemasaran dengan service excellence. Nilai beta diketahui sebesar 0.457 berati bahwa sistem informasi pemasaran mampu memberikan sumbangsih pengaruh terhadap service excellence sebesar 0.457 satuan jika faktor lain dianggap tetap.

Berdasarkan hasil pengujian hipotesis, maka diperoleh hasil bahwa sistem informasi pemasaran (X2) berpengaruh langsung terhadap service excellence $(\mathrm{Y})$. Hal ini berarti bahwa setiap perubahan yang terjadi pada sistem informasi pemasaran akan mengakibatkan perubahan pada service excellence yang dicapai, dimana semakin tinggi sistem informasi pemasaran akan semakin meningkatkan service excellence yang dicapai oleh manajemen Bank X dan begitu juga sebaliknya.

Hasil pengujian hipotesis ini membuktikan bahwa hipotesis 2 diterima secara signifikan. Dengan demikian, dapat dikatakan bahwa terdapat hubungan positif antara sistem informasi pemasaran terhadap service excellence. Hal ini mengindikasikan bahwa sistem informasi pemasaran mempunyai peranan 
yang besar dalam mewujudkan service excellence. Hasil penelitian ini mendukung penelitian sebelumnya yang dilakukan oleh Furey (1991, p.25) yang menyimpulkan bahwa sistem informasi pemasaran yang baik yang dgunakan menjadi faktor yang mendukung peningkatan service excellence.

\section{Pengaruh Sistem Kontrol terhadap Service Excellence} ini adalah :

Hipotesis yang diajukan dalam penelitian

H3 : Sistem kontrol berpengaruh positif dan signifikan terhadap service excellence.

Untuk menguji hipotesis yang diajukan, kita akan melihat uji $\mathrm{t}$ seperti yang sudah dilakukan sebelumnya dimana diketahui t hitung sebesar $9.445>$ dari $\mathrm{t}$ tabel 1.983, hal ini mengindikasikan bahwa secara parsial ada pengaruh yang kuat antara variabel sistem kontrol dengan service excellence. Nilai beta diketahui sebesar 0.474 memberikan makna bahwa sistem kontrol mampu memberikan sumbangsih pengaruh terhadap service excellence sebesar 0.474 satuan jika faktor lain dianggap tetap.

Berdasarkan hasil pengujian hipotesis, maka diperoleh hasil bahwa sistem kontrol (X3) berpengaruh langsung terhadap service excellence (Y). Hal ini berarti bahwa setiap perubahan yang terjadi pada sistem kontrol akan mengakibatkan perubahan pada service excellence yang dicapai, dimana semakin tinggi sistem kontrol akan semakin meningkatkan service excellence yang dicapai oleh manajemen Bank X dan begitu juga sebaliknya.

Hasil pengujian hipotesis ini membuktikan bahwa hipotesis 3 diterima secara signifikan. Dengan demikian, dapat dikatakan bahwa terdapat hubungan positif antara sistem control terhadap service excellence. Hal ini mengindikasikan bahwa sistem kontrol mempunyai peranan yang sangat besar dalam mewujudkan service excellence. Hasil penelitian ini mendukung penelitian sebelumnya yang dilakukan oleh Baldauf et al (2001), Oliver dan Anderson (1994) dan Zerbe et al (1998), yang menyimpulkan bahwa dengan sistem kontrol yang baik maka karyawan akan terdorong untuk bekerja atau berperilaku sebagaimana yang diharapkan oleh konsumen atau pelanggan dalam memberikan service excellence terhadap mereka.

\section{Kesimpulan}

1. Hasil penelitian ini menunjukkan bahwa variabel bebas yang terdiri dari interaksi antar departemen, sistem informasi pemasaran dan sistem kontrol mempunyai pengaruh yang signifikan terhadap variabel terikat yaitu service excellence. Hal ini menunjukkan bahwa ketiga variabel bebas tersebut secara bersamaan mempengaruhi service excellence yang terjadi di Bank X Pekanbaru. Ini berarti bahwa segala perubahan yang terjadi pada ketiga variabel bebas tersebut akan mengakibatkan perubahan terhadap service excellence yang dicapai. Dari hasil penelitian ini juga diketahui bahwa variabel sistem kontrol merupakan variabel yang paling dominan dalam mempengaruhi service excellence di Bank X Pekanbaru. Perubahan pada sistem kontrol yang dilaksanakan Bank $X$ akan mengakibatkan perubahan yang signifikan terhadap service excellence.

2. Variabel interaksi antar departemen diukur dengan indikator keeratan hubungan, kerjasama dan komunikasi antar departemen. Hasil penelitian menunjukkan bahwa interaksi antar departemen berpengaruh signifikan terhadap service excellence. Ini berarti bahwa segala perubahan yang terjadi pada interaksi antar departemen akan mengakibatkan perubahan terhadap service excellence yang dicapai.

3. Variabel sistem informasi pemasaran yang diukur dengan indikator pengumpulan informasi dan pendistribusian informasi lingkungan bisnis serta hardware software pendukung sistem informasi berpengaruh signifikan terhadap service excellence. Ini berarti bahwa segala perubahan yang terjadi pada sistem informasi pemasaran akan mengakibatkan perubahan terhadap service excellence yang dicapai.

4. Variabel sistem kontrol diukur dengan indikator pengawasan aktifitas, evaluasi aktifitas dan umpan balik aktifitas berpengaruh signifikan terhadap service excellence. Ini berarti bahwa 
segala perubahan yang terjadi pada sistem kontrol akan mengakibatkan perubahan terhadap service excellence yang dicapai

\section{Referensi (APA $6^{\text {th }}$ Style, Mendeley dsj)}

Aco, Hasanudin, 2010, Nasabah Premium Bank Mandiri Melonjak, Bisnis dan

Ekonomi, Tribunnews.com

Algifari (1997), “Analisis Regresi”, BPFE, Yogyakarta

Anderson, Erin dan Richard Oliver; 1987, Perspective on Behavior-Based Versus Outcomes-Based Salesforce

Control Systems, Journal of Marketing, Vol. 51

Antique.putra@ vivanews.com, $\quad 2009$, Pertumbuhan Nasabah Bank Mandiri Terbesar, Bisnis, Vivanews.com

Baldauf, Artur, David W Cravens dan Nigel Piercy; 2001; Examining Business Strategy, Sales Management, and Salesperson Antecedent of Sales Organisation Effectiveness, Journal of Personal Selling \& Sales Management, Vol. XXI. No. 2

Barata, Atep Adya. 2004. Dasar - dasar Pelayanan Prima. Jakarta : Elex Media Komputindo.

Beal, M. R, (2000), "Competing Effectively : Environmental Scanning, Competitive Strategy, and Organizational Performance in Small Manufacturing Firms", Journal of Small Business Management, January pp. 27-47

Customised Research Director Roy Morgan, 2009, Kenapa Nasabah Pindah Bank?, Ikatan Bankir Indonesia, infobanknews.com

Emory, W.C. and Cooper, D.R. (1991), “ Business Research Methods", Fouth ed Richard D Irwan, Inc. Boston

Ferdinand, Augusty, 2002, Structural Equation Modeling dalam Penelitian Manajemen, Badan Penerbit Universitas Diponegoro, Semarang

Furey, Timothy R, (1991), :How Information Power Can Improve Service Quality," Planning Review, May/June,pp.24-26

Hair, JR., Joseph F., Rolp E. Anderson, Ropnald L. Tatham and William C. Black, 1995,
Multivariate Data Analysis with Reading, Fourth Ed., Prentice Hall International, Inc

Hesselink, M. and Assem, Fritz V.D., (2002), "Building People and Organizational Excellence", The Start Service Excellence Program.

Indriantoro, Nur dan Supomo, 1999, Metodologi Penelitian Bisnis UntukAkuntansi \& Manajemen, BPFE Yogyakarta

Info Bank No. 302, Mei (2004)

Info Bank No. 315, Juni (2005)

Info Bank No. 325, April (2006)

Jaworski, Bernard J dan Deborah Mac Innis, 1989; Marketing Jobs and Management Control: $\quad$ Toward a Framework, Journal of MarketingResearch, Vol.XXVI

Johlke, Mark C, Dale F. Duhan, Roy D. Howell, dan Robert W. Wilkes,2000, An Integrated Model of Sales

Managers; Communication Practises, Journal of The Academic of Science, Vol. 28, No. 2

Johnston, Robert, (2004), "Towards a Better Understanding of Service Excellence”, Managing Service Quality, Vol. 14, No. 2, pp 129-133

Jones, Christoper, R., (2004), A "scorecard" for Service Excellence, Measuring business Excellence, Vol. 8, No. 4, pp 45-54

Kohli, Ajay. K, and Bernard J. Jaworski (1990)," Market Orientation The Construct, Research Propositions and Managerial Implications", Journal of Marketing 54 (April) pp. 1-18.

Kyle, P. W., (2007), "A Database for a Marketing Information System”, Emerald Backfiles

McClelland; Valorie A. and Richard, E.W, (1990)," Improve Lateral Communication", Personnel Journal, August, p. 32-38

Menon, Ajay, Bernard J. Jaworski dan Ajay K. Kohli, (1997), "Product Quality: Impact of interdepartmental Intereactions, "Journal of The Academy of $\quad$ Marketing Science 25(3) : pp. 187-200 
Morgan, Neil A,dan Nigel F. Piercy, (1998), "Interactions Between Marketing and Quality at the SBU Level: Influences and Outcomes,"Journal of The

Academy of Marketing

Science, Vol.26, No.3, pp. 190-208

Nur Pribadiyato dan Mudiantono, (2004), “ Analisis faktor-faktor Orientasi Pasar yang Mempengaruhi Kualitas Layanan dan Relevansinya terhadap Kinerja Perusahaan", Jurnal Studi Manajemen dan Organisasi, Vol. 1 /No. 2 / Juli

Mc.Carthy, E. Jerome, (1996),'Dasar - Dasar Pemasaran (Terjemahan) Penerbit Erlangga, Jakarta.

Mohr, Jakki \& John R. Nevin; 1990; Communication Strategies in Marketing Channels: A Theorical Perspective; Journal of Marketing.

Parasuraman, A., Zeithaml, Valerie A. \& Leonard L. Berry, 1988; Servqual; A Multiple-Item Scale for Measuring Consumer Percetions of Service Quality;Journal of Retailing, Vol. 64, No.1

Purwanto, Didik, 2010, 2014, Mandiri Targetkan 20 Juta Nasabah, Economy - Industri, Okezone.com

Rees, Ted; Randy Harris and Harry Lit, (1989), “ Work Team That Work", Manufacturing System, March, p. 42-45

Scott, Colin, (2010), Management Control System Support of Initiatives for Disruptive Student, International Journal of Educational Management, Vol. 25, No. 3, pp 212-222

Segars, A.H., Grover, V., (1998), “ Strategic Information System Planning Success: An Investigation of The Construct and Its Measurement", MIS Quartely, June

Seonmee Kim and Brian H. Kleiner, (1996),
Service excellence in the banking industry, Managing Service Quality, Vol. 6, No. 1, p. 22-27

Sugiyono, 2002, Metode Penelitian Bisnis, CV. Alfabeta, Bandung.

Sunanto, Taufuqurrahman dan Pangemanan, (2007), An Analysis of University Service Quality Gap and Student Satisfaction in Indonesia, The International Journal of Knowledge, Culture and Change Management, Vol 7, No. 7

Supranto, J.(2000), “ Statistik : Teori dan Aplikasi”, Jilid 1, Erlangga, Jakarta

Sutrisno Hadi, (1994), Statistik 2, Yogyakarta, Penerbit Andi Offset

Tjiptono, Fandy, (1997), Prinsip-Prinsip Total Quality Service, Yogyakarta, Penerbit Andi Offset

Tjiptono, Fandy. 2008. Service Management : Mewujudkan layanan prima. Yogyakarta : Andi.

Wakefield, Robin L; 2001; Service Quality; The CPA Journal

Wirtz, J. Heracleous, L. and Nitin Pangarkar, (2008), Managing human resources for service excellence and cost effectiveness at Singapore Airlines, Managing Service Quality, Vol.18, No.1, pp. 4-19

Zeithaml, Valerie A. Leonard L. Berry dan Parasuraman, A, 1988, Communication and Control Processes in the Delivery of Service Quality; Journal of Marketing, Vol. 52

Zerbe, Wilfred J, Dawn Dobni Gedaliahu, dan H. 